\title{
Wet Season Forage Production of Leucaena leucocephala cv Tarramba Planted in a Multiple Rows Configuration on Sandy Vertisol Soil at Naibonat, Kupang, East Nusa Tenggara-Indonesia
}

\author{
Debora Kana Hau ${ }^{1, *}$, Tony Basuki ${ }^{1}$, Twen O Dami Dato ${ }^{2}$, and J. Nulik ${ }^{1}$
}

\author{
${ }^{1}$ Balai Pengkajian Teknologi Pertanian (BPTP) Nusa Tenggara Timur \\ ${ }^{2}$ Universitas Nusa Cendana, Kupang \\ *Corresponding author.Email: debora_nulik@yahoo.com
}

\begin{abstract}
An experiment was conducted to measure forage production of Leucaena leucocephala cv Tarramba planted in a multiple rows of live fencing model. Plants were arranged in 8 rows which planted 2 meters from the main live fence of 1 ha land. The plants were cut at of $1 \mathrm{~m}$ height and then again at $\pm 30 \mathrm{~cm}$ from the ground level. Measurement of forage production was conducted to observe its ability in providing forage. Areas of $8 \times 20 \mathrm{~m}$ on each of the 4 land sides (replications) were allocated for the measurements. Half of the observation plot $(8 \times 10 \mathrm{~m})$ was allocated for 2 months cutting interval and the other half $(8 \times 10 \mathrm{~m})$ were allocated for 4 months cutting interval. Measurements conducted were on fresh and dry matter of edible parts (leaf and stem skin), plant height, stem diameter and number of branches. The results showed that each plant produced in average of 8 to 11 branches at 2 months interval, while the 4 months interval produced 2 to 4 branches only. Plant heights and diameters were $150-280 \mathrm{~cm}$ and $0.6-2.5 \mathrm{~cm}$ on the 2 months cutting interval, and from $465-560 \mathrm{~cm}$ and $2.6-3.4 \mathrm{~cm}$ on the 4 months cutting interval. At 2 months interval, two harvests produced a total edible DM of 4 ton. While the 4 months interval obtained 1 harvest with 3.6 tons DM per harvest, able to support about 4-5 heads of Bali cattle for fattening during the 4 months. Thus, during the wet season the 2 months cutting interval is recommended.
\end{abstract}

Keywords: Leucaena leucocephala cv Tarramba, Cutting interval, Edible dry matter, Bali Cattle, Wet Season, East Nusa Tenggara.

\section{INTRODUCTION}

The dry climate with long dry season (8-9 months) in East Nusa Tenggara has significant effects on the growth and productivity of forage supply for the ruminant livestock, especially cattle in the region. The negative effects including high calf mortality of Bali Cattle in West Timor (30 to 50\%) [1,2], long calving interval (2-3 year) of Sumba Ongole Cattle in Sumba Island, and low annual average live daily weight gain of cattle ( 0.2 to 0.3 $\mathrm{kg} / \mathrm{head} /$ day) $[3,4]$ in the whole province (Bali Cattle, Sumba Ongole Cattle as well as other local and introduced breeds) $[5,6]$.
The low beef cattle productivity in the region was mainly caused by extensive cattle farming with free grazing or pen feeding relied on native grasslands and grasses with low productivity and quality, especially during the dry season. With the long dry season, the region needs drought tolerant forage species with deep rooting system reaching the deep soil moisture to enable the plant to produce sufficient high quality and quantity forage such as Leucaena leucocephala with protein content of $>24 \%[7,8]$.

There are three main soil types in West Timor, i.e. red soil (alfisol) and black soil (mollisol) derived from rock parent material [9] (Mella), while the black vertisol soils 
are found mainly on the lowland rainfed rice area. The growth of Leucaena leucoephala planted on this difference soil types showed differences in its growth rate, where the best was observed when grown on the mollisols and vertisol soils [10]. Planting formation (thus plant density) may depend on the farming practices of the farmers. Farmers may grow the Leucaena plants as living fence, as monoculture plot, in alley cropping pattern, or multiple rows configuration on the border area of their land. These different planting formations, plant densities and soil type thus may give different production capacity in providing forage to feed cattle.

Thus, this experiment was conducted to measure forage production in the multiple rows planting formation on a sandy vertisol at Naibonat Village in Kupang District in East Nusa Tenggara, Indonesia. The area has an average long-term rainfall of around $1000 \mathrm{~mm}$, mainly fallen in three to four months (from December to April) [11].

\section{MATERIAL AND METHOD}

\subsection{Materials}

Leucaena leucocephala cv Tarramba [12] was planted in 2014 as forage source for cattle feeding on a sandy vertisol soil at Naibonat, East Kupang Sub-District of Kupang District in East Nusa Tenggara. Seedlings of Tarramba were transplanted in December 2014 and planted in multiple rows along the perimeter of $1 \mathrm{Ha}$ land with planting arrangement of 8 rows of $1 \mathrm{~m}$ x $0.5 \mathrm{~m}(1 \mathrm{~m}$ between the rows, and $0.5 \mathrm{~m}$ within the rows), started from $2 \mathrm{~m}$ away from the main live fence. Plants were cut down to $1 \mathrm{~m}$ height after one-year transplanting and then again down to $30 \mathrm{~cm}$ height from the ground in 2019 . The planting configuration model in this experiment thus provide a total area of $3,132 \mathrm{~m}^{2}$ with approximately 6,264 trees of Leucaena leucocephala cv Tarramba in the planted area. This model was introduced to the farmers who still want to use their land to grow other crops, especially food crop such as corn.

\subsection{Methods}

An area of $20 \mathrm{~m}$ by $11 \mathrm{~m}$ from each side of the 4 sides of the land was selected for forage measurements (thus there were 4 replications).

Measurements included: plant height, plant diameter, fresh and dry matter of forage, fresh and dry matter of stem skin, fresh and dry matter of stem, and chemical properties of edible dry matter (leaf and stem skin). Data were obtained from the measurements of 10 plants from the middle site of sampling area of each replication. The dry matters of the harvested materials were obtained through sun drying for 2 days. The measurements from the 10 sampling plants were then averaged and samples were taken for dry matter measurements. The tabulated data were then statistically analyzed using SPSS, which was followed by LSD test to compare between treatment means.

\section{RESULTS AND DISSCUSSIONS}

\subsection{Plant height and number of stem branches}

Plant height was significantly highest $(\mathrm{P}<0.01)$ in the four months cutting interval both compared to the $1^{\text {st }}$ and $2^{\text {nd }}$ harvests of the two months cutting intervals; while the $1^{\text {st }}$ harvest of the two months interval was significantly higher than the $2^{\text {nd }}$ harvest of the same interval (Table 1). It was observed that the number of shoots per plant was higher at the 2 months cutting intervals (8-12 shoots/stems) compared to the 4 months cutting interval. This was noticed that the shoots or stems branching from each main plant or tree at the start of regrowth may produce $8-12$ shoots or branching stems but by the time

Table 1. Plant growth, biomass production, and statistical analysis

\begin{tabular}{|c|c|c|c|c|c|c|c|}
\hline No & Treatment & $\begin{array}{c}\text { Plant height } \\
(\mathrm{cm})\end{array}$ & $\begin{array}{c}\text { Plant } \\
\text { diameter }(\mathrm{cm})\end{array}$ & $\begin{array}{l}\text { Leaf DM } \\
\text { (g/tree) }\end{array}$ & $\begin{array}{c}\text { Bark DM } \\
\text { (g/tree) }\end{array}$ & $\begin{array}{l}\text { Total Edible } \\
\text { DM (g/tree) }\end{array}$ & $\begin{array}{c}\text { Fresh stem } \\
\text { (g/tree) }\end{array}$ \\
\hline 1. & $\begin{array}{l}1^{\text {st }} \text { two months } \\
\text { cutting interval }\end{array}$ & $259.25^{b}$ & $1.20^{\mathrm{a}}$ & $349.36^{b}$ & $97.94^{b}$ & $447.30^{b}$ & $1191.50^{b}$ \\
\hline 2. & $\begin{array}{l}2^{\text {nd }} \text { two months } \\
\text { cutting interval }\end{array}$ & $165.50^{a}$ & $0.73^{a}$ & $152.60^{a}$ & $28.93^{a}$ & $188.76^{a}$ & $696.50^{a}$ \\
\hline 3. & $\begin{array}{l}\text { Total two harvests } \\
\text { of two month } \\
\text { cutting interval }\end{array}$ & - & - & $501.96^{d}$ & $134.10^{c}$ & $636.06^{d}$ & $1888.00^{c}$ \\
\hline 4. & $\begin{array}{l}4 \text { months cutting } \\
\text { interval (one } \\
\text { harvest) }\end{array}$ & $495.25^{c}$ & $2.67^{b}$ & $388.95^{c}$ & $203.15^{d}$ & $577.25^{c}$ & $3081.92^{d}$ \\
\hline
\end{tabular}

Numbers followed by different superscript within the column were significantly different $(\mathrm{P}<0.01)$ 
of advancement into 4 months some of the stem branches will die and will only left down to 2-4 stem branches at the 4 months interval harvest.

\subsection{Plant diameter}

The statistical analysis showed that plant diameter was the highest in the 4 months cutting interval (averaged $2.67 \mathrm{~cm}$ ) compared with that of the $1^{\text {st }}$ and $2^{\text {nd }}$ cutting interval branching stems (averaged 1.2 and 0.73 respectively), while there was no significant difference between the $1^{\text {st }}$ and the $2^{\text {nd }}$ harvest of the two month cutting interval $(\mathrm{P}>0.05)$.

\subsection{Leaf production}

Statistical analysis showed that there were significant differences in leaf DM production among the treatments $(\mathrm{P}<0.01)$, with the highest dry matter $(\mathrm{DM})$ production from the total 2 harvests of the 2 months interval cuttings compared to that of the single harvest of 4 months interval, and the leaf DM production of 4 month cutting interval was higher than that of the $1^{\text {st }}$ and the $2^{\text {nd }}$ harvests of the two months cutting intervals; the leaf DM production of the $1^{\text {st }}$ two month interval was higher than the $2^{\text {nd }}$ two month interval.

Thus, when harvested at 2 months interval during the rainy season the total area planted can provide about 3.14 tons of leaf DM. If harvested at the interval of 4 months, however, it can only provide 2.44 tons of leaf DM. Thus the, total leaf DM production of the two harvests of the two months interval gives more leaf DM than the 1 harvest at 4 months interval.

\subsection{Stem skin production}

In the field it is usually noticed that animals such as cattle and goat peal and eat the stem skin [13] of leucaena when the forage was offered with the whole plant attached to the animals. Cattle at free grazing also pealed and eat the stem skin of the living trees in the field.

The statistical analysis showed that the skin stem DM was highest in the single 4 month harvest compared to that of the $1^{\text {st }}$ and $2^{\text {nd }}$ as well as to the total of them both. The stem skin DM of $1^{\text {st }}$ two month cutting interval has higher weight than the $2^{\text {nd }}$ harvest (Table 1 ).

Thus from the area planted when harvested at 2 months interval it can provide (of the 2 harvests) 0.84 ton stem skin DM, while the 4 months cutting interval (1 harvest) provided 1.3 ton of stem skin DM.

\subsection{Total edible dry matter}

Statistical analysis indicated that the treatments have a high significant effect $(\mathrm{P}<0.01)$ on the total edible (stem skin and leaf) DM. The LSD test further showed that the total edible DM of the $1^{\text {st }}$ and $2^{\text {nd }}$ harvests of the two month cutting interval even significantly has higher edible DM $(\mathrm{P}<0.01)$ compared to the single cut edible DM of the 4 month cutting interval. The edible DM of the $1^{\text {st }}$ two month cutting interval was also significantly higher than that of the $2^{\text {nd }}$ harvest of the two month cutting interval $(\mathrm{P}<0.01)$.

From the data it can be calculated that stem skin portion in the edible forage may range from $15 \%$ in the 2 months cutting interval to $35 \%$ in the 4 months cutting interval, which may also reduce the quality of the feed, especially protein content (may range from $21 \%$ down to $17.8 \%$ ) using the standard protein content of $24 \%$ in the leaf [14] DM and $6.5 \%$ in the stem skin.

The multiple rows configuration planting of Tarramba in this experiment may produce a total of edible forage from in the 4 months single harvest and approximately 3.6 tons DM and a total of 4 ton from $1^{\text {st }}$ and $2^{\text {nd }}$ of the two months interval cutting which may support to feed 4-5 Bali Cattle of $250 \mathrm{~kg} / \mathrm{head}$.

\subsection{Stem production}

Fresh stem weight was highest in the 4 months cutting interval compared to the $1^{\text {st }}$ and $2^{\text {nd }}$ harvests of the twomonths cutting interval and even compared to the total weight of them both. Fresh stem weight was higher in the $1^{\text {st }}$ harvest of the two-months cutting interval compared to that of the $2^{\text {nd }}$ harvest.

Leucaena wood is known to have good value for making paper and rayon, as well as for generating power [15]. Therefore, if wood would also be the target of planting leucaena then the longer the cutting interval would be better in producing more wood. However, as the current experiment and the planting of leucaena was to provide sufficient forage or edible DM for feeding cattle, the priority would be for leaf production or edible DM.

\section{CONCLUSSION}

Better edible DM was produced by the 2 months cutting interval, which was the total of both harvests. This DM availability may be able to support feeding of 3-4 fattening cattle of $250 \mathrm{~kg} /$ head for 4 months, during the wet season (January to April). Thus, it is recommended to use 2 months cutting interval to obtain more forage compared to 4 months cutting interval.

\section{AUTHORS' CONTRIBUTIONS}

All authors contributed to the planning of the experiment for measuring the wet season production of Tarramba Leucaena and to do proof reading of the paper. Debora Kana Hau was responsible for getting the team to work together and making sure the writing of the paper. Tony Basuki contribute to the identification of soil type. Twen Dami Dato was responsible biomass production 
measurements. Jacob Nulik was responsible for tabulating and running the statistical analysis of the wet season biomass production.

\section{ACKNOWLEDGMENTS}

The material for planting of the experiment plot Leucaena leucoephala cv Tarramba seed was imported from Australia under the ACIAR project "Improving smallholder cattle fattening systems based on forage tree legume diets in eastern Indonesia and northern Australia" between 2013-2017 in East and West Nusa Tenggara.

\section{REFERENCES}

[1] Jelantik IGN, Mullik ML, Leo-Penu C, Copland R. 2010. Factors affecting the response of Bali cattle (Bos sondaicus) calves to supplementation prior to weaning. Anim Prod Sci. 2010. doi:10.1071/AN09217

[2] Mayberry D, Kana Hau D, Dida PR, Bria D, Praing J, Dule Mata A, Budisantoso E, Dalgliesh N, Bell L and Nulik J. 2020. Herbaceous legumes provide multiple options for increasing beef cattle productivity in eastern Indonesia. Livest Sci. 2020.

[3] Nulik J, Dalgliesh N, Cox K, and Gabb S. 2013. Integrating Herbaceous Legumes into Crop and Livestock Systems in Eastern Indonesia. ACIAR Monograph 154.

[4] Nulik J. Inovasi Teknologi Hijauan Pakan Berbasis Legum Di Lahan Kering Iklim Kering Mendukung Pengembangan Ternak Sapi. $2021 \quad$ (Elma Karmawati II, ed.). Bogor: IAARD PRESS.

[5] Nulik J and Kana Hau D. 2015. Daily Body Weight Gain of Bali Cattle Fed with Leucaena Leucocephala as the Main Ration in West Timor, East Nusa Tenggara, Indonesia. In: Proceedings, The 6th ISTAP International Seminar on Tropical Animal Production. Gajah Mada University; 2015:147-150.

[6] Kana Hau D and Nulik J. 2015. Body Weight Gain Response of Sumba Ongole Cattle to the Improvement of Feed Quality in East Sumba District, East Nusa Tenggara, Indonesia. In: PROCEEDINGS, The 6th ISTAP International Seminar on Tropical Animal Production. ; 143-150.

[7] Nulik J. 2014. Leguminosa Pakan Sebagai Sumber Hijauan Berkualitas - Lesson Learn Pengembangan Pakan Murah di NTT. In: Seminar Nasional III HITPI. Bukittinggi: Fakultas Peternakan Universitas Andalas, 33-44.

[8] Nulik J, Kana Hau D, Halliday MJ, Shelton HM. 2019. Tarramba leucaena: A success story for smallholder bull fattening in eastern Indonesia. Trop Grasslands-Forrajes Trop. 7(4). doi:10.17138/TGFT(7)410-414

[9] Mella WII. 2003. Genesis and Fertility of Alfisols and Mollisols formed on Raised Coral Reef in West Timor, Indonesia. Ph.D. Thesis. University of Saskatchewan.

[10] Nulik J D, Kana Hau D, Pakereng Ch, Edison RG, Liubana D, Ara SP and Giles H. 2013. Establishment of Leucaena leucocephala cv. Tarramba in eastern Indonesia. Trop GrasslandsForrajes Trop. 1(1):111-113.

[11] Nait C, Bisri M, Soetopo W, Prayogo T, Limantara LM and Krisnayanti DS. 2021. Identification of climate change impact at Raknamo Dam, Kupang, Indonesia. In: The 5th International Conference on Climate Change 2020. ; 2021.

[12] Dalzell SA. 2019. Leucaena cultivars - current releases and future opportunities. Trop GrasslandsForrajes Trop. (7)56-64

[13] Cowley FC and Roschinsky R. 2019. Incorporating leucaena into goat production systems. Integrando leucaena en sistemas de producción de caprinos. Trop Grasslands-Forrajes Trop. 2019;7(2):173181.

[14] De Angelis A, Gasco L, Parisi G and Danieli PP. 2021. A Multipurpose Leguminous Plant for the Mediterranean Countries: Leucaena leucocephala as an Alternative Protein Source: A Review. Animals. 2021;11, 2230.

[15] Masafu MM. 2006. The Evaluation of Leucaena leucocephala (Lam) De Wit: A Renewable Protein Supplement For Low Quality Forages. University of South Africa. 